\title{
Contents List
}

Preface ...................... . . . . . . .

Biomedical Results of the Skylab Programme

E. L. Miched, R. S. Johnston and L. F. Dietrlein

Biomedical Results of the Skylab Program . . . . . . . . . . . . . . . . . . . 3

H. KALDEWEY

\section{Symposium on Gravitational Physiology}

Considerations of Geotropism in Plants . . . . . . . . . . . . . . 21

D. J. OsBorne

Hormones and the Growth of Plants in response to Gravity . . . . . . . . . . . 37

N. P. Dublnin and E. N. VaULina

The Evolutionary Role of Gravity . . . . . . . . . . . . . . . . . . . . . . . 47

S. J. GouLd

Weight and Shape . . . . . . . . . . . . . . . . . . . . . . . . . . . 57

R. S. Young

Gravity and Embryonic Development . . . . . . . . . . . . . . . . . . 69

L. H. VoGT

Physiological Effects of Sustained Acceleration . . . . . . . . . . . . . . . 77

A. H. Sмith

Physiological Changes associated with Long-Term Increases in Acceleration . . . . . 91

L. I. KakuRin, M. P. Kuzmti, E. I. Matsnev and V. M. Mukhailov

Physiological Effects induced by Antiorthostatic Hypokinesia . . . . . . . . . . . 101

A. GraybieI.

The Prevention of Motion Sickness in Orbital Flight . . . . . . . . . . . . . . . 109

G. D. Whedon, L. Lutwak, P. Rambaut, M. Whittle, C. Leach, J. Reid and M. Smith Mineral and Nitrogen Metabolic Studies on Skylab Flights and Comparison with Effects of Earth Long-Term Recumbency . . . . . . . . . . . . . . . . . . . . . . . 119

A. R. Kotovskaya

Human Tolerance to Acceleration after exposure to Weightlessness . . . . . . . . 129

V. S. Oganov and A. N. Potapov

On the Mechanisms of Changes in Skeletal Muscles in the Weightless Environment . . 137

O. G. Gazenko, N. N. Gurovsky, A. M. Genin, I. I. Bryanov, A. V. Eryomin and A. D.

Egonov

Results of Medical Investigations carried out on board the Salyut Orbital Stations . . 145

G. SEIBERT

Spacelab and its Utilization for Biomedical Experiments . . . . . . . . . . . . . 153 


\section{Radiation Biology}

Yo. A. Akatov, A. N. Gladilkin, I. V. Ignatov, S. B. Kozlova, A. V. Kolodin, R. A. Kozin, V. I. Popov, L. N. Seliverstov, V. G. Semyonov, M. A. SychKov, B. I. SolyaNOV and V. V. YuRgov

Irradiation of Bio-objects aboard the Cosmos 690 Biosatellite . . . . . . . . . . . 165

Yo. G. Grigoriev, E. A. Ilyin, Yu. P. Druzhinin, L. V. Serova, V. I. Popov, A. D. Noskin, R. A. Kuzin, Yu. I. Kondratyev, M. P. Kalandarova, G. N. PodluzhnaYa, B. N. Yurov, V. K. Golov, V. I. Milyavsky and V. V. Verigo

Investigation of Radiation Sensitivity in Mammals under long Duration Weightlessness 173

M. P. Kalandarova, V. V. Verigo, G. N. Podlyzhnaya, G. P. Rodina, L. V. Serova and N. A. Cheldiaya

Effect of Irradiation in the Space Environment on the Blood-forming System in Rats $\quad 179$

I. Ahlers, E. Mišúrová, M. Praslička and R. A. Tigranyan

Biochemical changes in Rats flown on board the Cosmos 690 Biosatellite . . . . . . 185

L. D. Szabó, A. Benkó, L. Gyenge and T. Predmerszky

Study of the Biochemical Indicators of Chronic Irradiation in Rats . . . . . . . . 189

M. W. Mirler, G. E. Kaufman and H. D. Matllie

Pioneer 10 and 11 Jovian Encounters: Radiation Dose and Biological Lethality . . . 195

E. N. VAUlina, L. N. Kostina and A. L. Mashinsky

Cytogenetic Analysis of Seeds of Crepis capillaris (L) Wallr. exposed on the Satellite

Cosmos 613 . . . . . . . . . . . . . . . . . . . . . . . . . . . . . . . 201

P. J. McNulty, V. P. Pease and V. P. Bond

Role of Cerenkov Radiation in the Eye-flashes observed by Apollo Astronauts . . . 205

R. Beadjean, W. ENge, W. Herrmann and K.-P. Bartholomä

Study with a Multi-threshold HZE-particle Dosimeter using Plastic Detectors . . . . 219

A. Pfister, C. Nogues and R. Kaiser

Lesional Effects of Primary Cosmic Heavy Tons on Rat Brain . . . . . . . . . . . 225

J. Miquel, E. V. Benton and G. WAELCH

Effects of ${ }^{40} \mathrm{Ar}$ on the Nerve Cells of Drosophila (Abstract only) . . . . . . . . . . 231

H. BÜCKER, R. FACIUS and M. SCHÄFER

The Biostack as an approach to High LET Research . . . . . . . . . . . . . . . 233

H. BüCker, D. Hilofbrand, G. Reitz and M. Schärer

Localization and Track Evaluation of HZE Particles . . . . . . . . . . . . . . 241

M. I. Minkova, N. I. Ryzhov and T. P. Pantev

Influence of Heavy Ions on the Transforming Activity of DNA . . . . . . . . . 247

E. E. Kovalev and T. YA. Riabova

Study of Basic Electrostatic Radiation Shield Characteristics on board the Cosmos 605

Satellite . . . . . . . . . . . . . . . . . . 251

A. S. Ushakov and T. F. Vlasova

Gravitational Biology

Amino Acid Spectrum of Human Blood Plasma during Space Flight and in Antiortho-

static Hypokinesia. . . . . . . . . . . . . . . . . . . . . . . . . . . . . . 257

E. S. Mainyan and E. A. Kovalengo

Space Flight Effects on the Bioenergetics of the Skeletal Muscles in Rats . . . . . . 263

N. Pace, A. M. Kodama, D. C. Price, B. W. Grunbaum, D. F. Rahlmann and B. D. NewSOM

Body Composition Changes in Men and Women after 2-3 weeks of Bed Rest . . . . 269

KH. Kr. Yardluti, T. D. VAstuyeva and D. A. Alekseev

Antiorthostatic Test as a model to study Antigravity Mechanisms of the Cardiovascu-

lar System . . . . . . . . . . . . . . . . . . . . . 275

V. P. BYchKov and M. V. MarkaRYaN

Metabolic Processes in Hypokinetic and Rehabilitated Men . . . . . . . . . . . . 281

T. N. Krupina, B. M. Fyodorov, L. M. Frlatova, N. I. Tsyganova and E. I. Matsnev

Effect of Antiorthostatic Bed Rest on the Human Body . . . . . . . . . . . . 285 
E. B. Shulzhenko, I. F. Vil-Vilyams, M. A. Khudyakova and A. I. Grigoriev

Deconditioning during Prolonged Immersion and possible Countermeasures . . . . . 289

I. Y. YAkovleva, B. B. Bokhov and L. N. KorniLova

Study of Space Perception Function during Simulation of certain Space Flight Factors . 295

B. S. Katkovsky and YU. D. Pomyotov

Cardiac Output during Physical Exercises following Real and Simulated Space Flight . 301

G. I. Kozyrevskaya, A. I. Grigoriev and Yu. V. Natochin

Renal Osmoregulatory Function during Simulated Space Flight . . . . . . . . . . 307

V. I. MYasnikov, O. P. Kozerenko and N. M. Rudomyotkin

Characteristics of Postural Self-Regulation in Complex Spatial Environments and

After-Effects of Weightlessness . . . . . . . . . . . . . . . . . . . . 313

P. Groza, R. Cârmaciu, E. Nicolescu, S. Cananău, R. Vkâncianu and D. Bobic

Hypergravitation and Sympatho-Adrenergic Reactivity . . . . . . . . . . . . . 319

T. N. Krupina, G. P. Mikhailovsky, A. Ya. Tizul, M. P. Kuzmin, N. I. Tsyganova and E. B. ShULZHENKo

A Study of the Cumulative Effects of Repeated Exposures to Radial Accelerations . . 325

L. Novák

Heat Exchange between the Organism and Environment under conditions of Weight. lessness; Methodical Approach . . . . . . . . . . . . . . . . . . . . 329

\section{Planetary Quarantine}

V. I. Vashrov, G. V. Scheglova, N.V. Ramkova, E. S. Zavolnaya, K. O. Fedorova and E. K. Skvortsova

Effect of Extreme Factors on Micro-Organisms used for the Control of the Effectiveness of Sterilization . . . . . . . . . . . . . . 337

N. V. Ramkova, A. G. Nekhorosheva, S. V. Lysenko, L. B. Chudnova, N. V. Kareev and G. V. SCHEGLOVA

Sterilization of a Biological Analyser . . . . . . . . . . . . . . . . . . 341

\section{Exobiology}

A. A. Imshenetsky, M. D. Evdokimova and G. G. Sotnikov

On Methods of Detection of Extraterrestrial Life . . . . . . . . . . . . . . . . 345

S. M. Siegel and T. W. SPEITEL

Performance of Fungi in Low Temperature and Hypersaline Environments . . . . . 351

H. BÜCk.R, R. Factus, G. Reitz, C. Thomas and H. WollenhadPT

Effect of Space Factors on Escherichia coli B/r Cells . . . . . . . . . . . . . . . . 355

A. A. Imshenetsky, S. V. Lysenko, G. A. Kazakov and N. V. Ramkova

On Micro-Organisms of the Stratosphere . . . . . . . . . . . . . . . . 359

N. J. Pderner and S. M. Siegel

Geomycology . . . . . . . . . . . . . . . . . . . 363

Index of Authors . . . . . . . . . . . . . . . . . . . . 367 
